\title{
Dynamics of exhaled breath temperature after smoking a cigarette and its association with lung function changes predictive of COPD risk in smokers: a cross-sectional study
}

\author{
Ivana Huljev Šipoš ${ }^{1}$, Slavica Labor ${ }^{2,3}$, Iva Jurić ${ }^{4}$, Davor Plavec ${ }^{3,5}$, Kristian Vlahoviček $^{5,6}$, \\ Siniša Bogović ${ }^{7}$, Justinija Pavkov Vukelić ${ }^{8}$, and Marina Labor ${ }^{2,3}$ \\ ${ }^{1}$ Department of Pulmonology, General Hospital Šibenik, Šibenik, Croatia \\ ${ }^{2}$ Department of Pulmonology, University Hospital Center Osijek, Osijek, Croatia \\ ${ }^{3}$ Faculty of Medicine, J. J. Strossmayer University of Osijek, Osijek, Croatia \\ ${ }^{4}$ Department of Cardiology, University Hospital Center Osijek, Osijek, Croatia \\ ${ }^{5}$ Research Department, Srebrnjak Children's Hospital, Zagreb, Croatia \\ ${ }^{6}$ Bioinformatics Group, Division of Molecular Biology, Department of Biology, Faculty of Science, University of \\ Zagreb, Zagreb, Croatia \\ ${ }^{7}$ Department of Cardiac Surgery, University Hospital Center Osijek, Osijek, Croatia \\ ${ }^{8}$ Department of Medicine, County General Hospital Našice, Našice, Croatia
}

[Received in October 2018; Similarity Check in October 2018; Accepted in May 2019]

\begin{abstract}
Exhaled breath temperature (EBT) is a biomarker of inflammation and vascularity of the airways already shown to predict incident COPD. This cross-sectional study was aimed to assess the potential of EBT in identifying "healthy" smokers susceptible to cigarette smoke toxicity of the airways and to the risk of developing COPD by analysing the dynamics of EBT after smoking a cigarette and its associations with their demographics (age, smoking burden) and lung function. The study included 55 current smokers of both sexes, 29-62 years of age, with median smoking exposure of 15 (10-71.8) pack-years. EBT was measured at baseline and 5, 15, 30, 45, and 60 min after smoking a single cigarette. Lung function was measured with spirometry followed by a bronchodilator test. To compare changes in EBT between repeated measurements we used the analysis of variance and the area under the curve (EBT (EC $_{\text {) }}$ ) as a dependent variable. Multivariate regression analysis was used to look for associations with patient characteristics and lung function in particular. The average $\left( \pm\right.$ SD) baseline EBT was $33.42 \pm 1.50{ }^{\circ} \mathrm{C}$. The highest significant increase to $33.84(1.25){ }^{\circ} \mathrm{C}$ was recorded 5 min after the cigarette was smoked ( $\mathrm{p}=0.003$ ), and it took one hour for it to return to the baseline. $\mathrm{EBT}_{\mathrm{AUC}}$ showed significant repeatability ( $\mathrm{ICC}=0.85, \mathrm{p}<0.001)$ and was significantly associated with age, body mass index, number of cigarettes smoked a day, baseline EBT, and baseline $\mathrm{FEF}_{75}\left(\mathrm{R}^{2}=0.39, \mathrm{p}<0.001\right.$ for the model $)$. Our results suggest that EBT after smoking a single cigarette could be used as early risk predictor of changes associated with chronic cigarette smoke exposure.
\end{abstract}

KEY WORDS: EBT; cigarette smoking; COPD risk; small airway dysfunction; cigarette smoke toxicity

New estimates predict that by 2020 chronic obstructive pulmonary disease (COPD) will become the third leading cause of death worldwide (1). Its major aetiopathogenic feature - the damage of the small airways (small airway dysfunction) - is present from the early stages of COPD and becomes more prominent as the disease progresses (2). However, current tests of small airway function have not been widely accepted for routine use in the early stages of the disease because their results vary significantly, there are no validated reference ranges, CT scans follow complex protocols, and/or because they cost a lot. Diagnosing COPD in later stages, however, means that the lungs have already been severely damaged. It is therefore essential to find a

Corresponding author: Davor Plavec, $\mathrm{MD}, \mathrm{PhD}$, Research Department, Srebrnjak Children's Hospital Zagreb, Srebrnjak 100, HR-10000 Zagreb, Croatia,E-mail:plavec@bolnica-srebrnjak.hr new, possibly non-invasive early-stage diagnostic method to prevent the development of the disease. One of the methods showing potential in that respect is exhaled breath temperature (EBT) measurement. It has recently been introduced as a new, non-invasive marker of inflammation of the respiratory tract in patients with respiratory diseases (asthma, COPD, cystic fibrosis, bronchial carcinoma), as it was consistently and significantly higher than in healthy controls $(3,4)$. As a biomarker of inflammation and vascularity of the airways it can be used alone or in combination with other inflammatory biomarkers like leukocyte and eosinophil counts, exhaled nitric oxide (FeNO), C-reactive protein, and club cell secretory protein $(3,4)$.

Airway sensitivity to cigarette smoke is somewhat specific in COPD, as less than $30 \%$ of smokers develop 
COPD during their lifetime. Our recent cohort research (4) showed that an increase in EBT five minutes after smoking a single cigarette could be moderately predictive of incident COPD in smokers over two years of follow-up. What that study missed to investigate was the dynamics of EBT after a single smoked cigarette and how this dynamics relates to chronic cigarette smoke exposure and lung function, small airway dysfunction in particular, as an early marker of future COPD. Therefore, the aim of this study was to assess the potential of the dynamics of EBT after smoking a single cigarette in identifying smokers prone to COPD by associating it with lung function (small airway dysfunction) and demographics (age, sex, smoking burden).

\section{PARTICIPANTS AND METHODS}

\section{Participants and study design}

This cross-sectional study included a group of 55 current smokers: 43 women and 12 men, 29-62 years of age, whose median smoking exposure was 15 pack-years (Table 1). It was a sub-study of the MARKO project published elsewhere (5). None of the participants had a history of chronic respiratory disorders or cardiovascular or other significant systemic diseases. The testing was conducted at least four weeks after an acute respiratory episode and participants were instructed to restrain from smoking, eating, drinking, and taking any medicines at least two hours before and during the testing.

The diagnostic workup included medical history, physical examination, baseline EBT, and EBT at 5, 15, 30, 45 , and $60 \mathrm{~min}$ after having smoked a cigarette, and lung function measurements followed by a bronchodilator test. In a random subsample of 12 participants EBT measurements were repeated at the same time on another day to test the repeatability of EBT dynamics. The study was conducted in accordance with the ethical principles of the Declaration of Helsinki and was approved by the ethics committees of the Srebrnjak Children's Hospital (No. 4/2010) and the University Hospital Center Osijek (No. 25-1:103594/2014). All patients provided written informed consent.

\section{Lung function}

Lung function was measured with spirometry using a computerised pneumotachgraph (Jaeger ${ }^{\circledR}$, CareFusion, Yorba Linda, CA, USA) according to the ATS/ERS guidelines (6), and the record included the best of three technically satisfactory attempts. The bronchodilator test was done by repeating spirometry $20 \mathrm{~min}$ after salbutamol $(400 \mu \mathrm{g})$ inhalation using an inhalation chamber. Spirometric indices - forced vital capacity (FVC), forced expiratory volume in one second $\left(\mathrm{FEV}_{1}\right), \mathrm{FEV}_{1} / \mathrm{FVC}$ ratio, peak expiratory flow (PEF), and forced expiratory flow at $75 \%$ of FVC $\left(\mathrm{FEF}_{75}\right)$ - were recorded as absolute values, percentages of the predicted values, percentiles, and z-scores according to Quanjer $(7,8)$.

\section{Exhaled breath temperature}

EBT was measured using an X-Halo ${ }^{\circledR}$ device (Delmedica Investments, Singapore) according to a previously validated method $(9,10)$. We measured multiple expirations, with the device signalling the end of measurement when EBT reached thermal equilibrium. Details about the measurement have been described elsewhere (3). In short, patients inhaled through the nose and exhaled into the device in a tidal breathing pattern through the mouth. Room temperature was $22-25^{\circ} \mathrm{C}$ and relative humidity $30-60 \%$. According to Popov et al. (10), measurement precision is $0.01{ }^{\circ} \mathrm{C}$ and reproducibility 0.99 (intra-class correlation coefficient).

\section{Data analysis}

For statistical analysis we used STATISTICA version 12 (StatSoft, Inc., Tulsa, OK, USA). The minimal sample size of 39 for multivariate analysis of up to five independent variables was calculated using the expected R-squared of 0.36 , statistical power of $90 \%$, and alpha of 0.05 . Numerical data are expressed as means and standard deviations (SD) or as medians and interquartile ranges, depending on the type of distribution. Normality of distribution was tested with the Kolmogorov-Smirnov test. Categorical data are expressed as frequency and proportion (\%). Numerical data

Table 1 Baseline characteristics of the participants $(n=55)$

\begin{tabular}{lcccc}
\hline & Mean & SD & \multicolumn{2}{c}{ Range } \\
\hline Age $($ years $)$ & 41.8 & 9.2 & 28.5 & 61.9 \\
\hline Women $(\%)^{*}$ & $43(78.2)$ & & & \\
\hline BMI $\left(\mathrm{kg} / \mathrm{m}^{2}\right)$ & 24.54 & 4.09 & 17.53 & 33.46 \\
\hline Smoking (years) & 20.7 & 8.8 & 6.0 & 42.0 \\
\hline Cigarettes per day & 15.9 & 7.7 & 5 & 35 \\
\hline Cigarette smoking (pack-years) ${ }^{* *}$ & $15(7-24)$ & & 10.0 & 71.8 \\
\hline Systolic blood pressure $(\mathrm{mmHg})$ & 123 & 10 & 110 & 150 \\
\hline Diastolic blood pressure $(\mathrm{mmHg})$ & 76 & 8 & 60 & 100 \\
\hline Hearth rate per minute & 71 & 8 & 58 & 91
\end{tabular}

* results expressed as frequency (\%). ** results expressed as median (interquartile range). SD - standard deviation; BMI - body mass index 
not following normal distribution were normalised. Repeated measurements of EBT changes from baseline were tested with the analysis of variance (ANOVA). EBT changes from baseline until minute 60 were also calculated as the area under the curve $\left[\mathrm{EBT}_{\mathrm{AUC}}\right.$, expressed in ${ }^{\circ} \mathrm{C}^{*}$ minutes $\left.\left({ }^{\circ} \mathrm{C}_{\text {min }}\right)\right]$ for each participant and analysed as a dependent variable. The repeatability of $\mathrm{EBT}_{\mathrm{AUC}}$ was tested using concordance correlation in a group of 12 participants and expressed as an intra-class correlation coefficient (ICC). The group was also divided into two subgroups regarding the $\mathrm{EBT}_{\mathrm{AUC}}$ (increase vs. decrease in EBT). The two subgroups were compared using Student's $t$-test. The association between $\mathrm{EBT}_{\mathrm{AUC}}$ and independent variables was assessed with univariate and multivariate regression analysis. Independent variables showing an association with $\mathrm{EBT}_{\mathrm{AUC}}$ of $\mathrm{p}<0.10$ were used for a multivariate regression model using a stepwise approach. The final regression model was checked against significantly associated variables with variance inflation factor checked. $\mathrm{P}<0.05$ was considered statistically significant for all tests, corrected for multiple comparisons.

\section{RESULTS}

Table 2 shows lung function measurements in all participants. At baseline, mean EBT of all participants was $33.42 \pm 1.50{ }^{\circ} \mathrm{C}$, then rose to its highest $33.84 \pm 1.25^{\circ} \mathrm{C} 5 \mathrm{~min}$ after the smoked cigarette $(\mathrm{p}=0.003)$, and dropped back to $33.51(1.53){ }^{\circ} \mathrm{C}(\mathrm{p}=0.999$, Table 3) $60 \mathrm{~min}$ after the smoked cigarette. This pattern, expressed as area under the curve $\left(\mathrm{EBT}_{\mathrm{AUC}}\right)$, showed significant repeatability $(\mathrm{ICC}=0.85$, $\mathrm{p}<0.001)$.

The participants, however, exhibited two distinct patterns: 37 had an increase in EBT after having smoked a cigarette, and 18 had a decrease $\left(\mathrm{EBC}_{\mathrm{AUC}}\right.$ was significantly different, $\mathrm{p}<0.001$, Table 3 ), even though these two groups did not differ in baseline characteristics or lung function parameters ( $p>0.05$ for all).

In univariate analysis, $\mathrm{EBT}_{\mathrm{AUC}}$ was significantly associated with baseline EBT, baseline and postbronchodilator $\mathrm{FEV}_{1} / \mathrm{FVC}$ (expressed as absolute values, Z-scores and percentiles), baseline $\mathrm{FEV}_{1}$ (expressed as z-score and $\%$ predicted), post-bronchodilator $\mathrm{FEV}_{1}$ (\% predicted),

Table 2 Baseline and post-bronchodilator lung function parameters $(\mathrm{n}=55)$

\begin{tabular}{|c|c|c|c|c|c|}
\hline & & Mean & SD & Minimum & Maximum \\
\hline \multirow{11}{*}{$\begin{array}{l}\stackrel{\Xi}{\Xi} \\
\tilde{\Xi} \\
\tilde{\varpi}\end{array}$} & FVC (\% predicted) & 96.20 & 8.19 & 76.10 & 113.30 \\
\hline & FVC (percentile) & 40.12 & 21.05 & 2.45 & 81.41 \\
\hline & FVC (z-score) & -0.30 & 0.65 & -1.97 & 0.89 \\
\hline & $\mathrm{FEV}_{1}(\%$ predicted $)$ & 98.43 & 11.70 & 75.82 & 128.97 \\
\hline & $\mathrm{FEV}_{1}$ (percentile) & 45.51 & 27.97 & 3.76 & 98.33 \\
\hline & $\mathrm{FEV}_{1}$ (z-score) & -0.12 & 0.93 & -1.78 & 2.13 \\
\hline & $\mathrm{FEV}_{1} / \mathrm{FVC}$ & 0.83 & 0.07 & 0.67 & 0.95 \\
\hline & $\mathrm{FEV}_{1} / \mathrm{FVC}$ (percentile) & 57.06 & 29.43 & 2.75 & 98.25 \\
\hline & $\mathrm{FEV}_{1} / \mathrm{FVC}$ (z-score) & 0.30 & 1.11 & -1.92 & 3.30 \\
\hline & $\mathrm{FEF}_{75}$ (percentile) & 60.93 & 25.62 & 19.47 & 99.13 \\
\hline & $\mathrm{FEF}_{75}(\mathrm{z}$-score $)$ & 0.42 & 0.92 & -0.86 & 2.38 \\
\hline \multirow{12}{*}{ 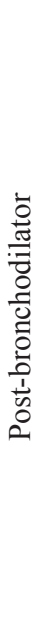 } & FVC (\% predicted) & 97.89 & 8.33 & 80.87 & 114.11 \\
\hline & FVC (percentile) & 44.42 & 22.34 & 5.85 & 87.43 \\
\hline & FVC (z-score) & -0.17 & 0.66 & -1.57 & 1.15 \\
\hline & $\mathrm{FEV}_{1}(\%$ predicted $)$ & 102.22 & 10.15 & 80.05 & 128.14 \\
\hline & $\mathrm{FEV}_{1}$ (percentile) & 55.13 & 24.97 & 7.04 & 97.82 \\
\hline & $\mathrm{FEV}_{1}(\mathrm{z}$-score $)$ & 0.18 & 0.80 & -1.47 & 2.02 \\
\hline & $\mathrm{FEV}_{1}$ change $(\%)$ & 4.16 & 4.69 & -4.77 & 15.16 \\
\hline & $\mathrm{FEV}_{1} / \mathrm{FVC}$ & 0.85 & 0.06 & 0.71 & 0.95 \\
\hline & $\mathrm{FEV}_{1} / \mathrm{FVC}$ (percentile) & 65.61 & 26.97 & 9.89 & 98.27 \\
\hline & $\mathrm{FEV}_{1} / \mathrm{FVC}$ (z-score) & 0.60 & 1.02 & -1.29 & 3.20 \\
\hline & $\mathrm{FEF}_{75}$ (percentile) & 69.84 & 20.70 & 23.10 & 98.84 \\
\hline & $\mathrm{FEF}_{75}(\mathrm{z}$-score $)$ & 0.67 & 0.75 & -0.74 & 2.27 \\
\hline
\end{tabular}

$\mathrm{SD}$ - standard deviation; FVC - forced vital capacity; $\mathrm{FEV}_{1}$ - forced expiratory volume in 1 second; $\mathrm{FEF}_{75}$ - forced expiratory flow at $75 \% \mathrm{FVC}$ 
Table 3 Changes in EBT after smoking a cigarette $(n=55)$

\begin{tabular}{|c|c|c|c|c|c|c|c|c|}
\hline \multirow[b]{3}{*}{ Baseline EBT $\left({ }^{\circ} \mathrm{C}\right)$} & \multicolumn{4}{|c|}{ All $(n=55)$} & \multicolumn{2}{|c|}{$\begin{array}{c}\text { Increase in EBT } \\
(n=37)\end{array}$} & \multicolumn{2}{|c|}{$\begin{array}{c}\begin{array}{c}\text { Decrease in EBT } \\
(n=18)\end{array} \\
\end{array}$} \\
\hline & \multirow{2}{*}{\begin{tabular}{|l|} 
Mean \\
33.46
\end{tabular}} & \multirow{2}{*}{$\begin{array}{c}\text { SD } \\
1.49\end{array}$} & \multicolumn{2}{|c|}{ Range } & \multirow{2}{*}{\begin{tabular}{|c|} 
Mean \\
33.18
\end{tabular}} & \multirow{2}{*}{$\begin{array}{c}\text { SD } \\
1.66\end{array}$} & \multirow{2}{*}{$\begin{array}{c}\text { Mean } \\
33.92\end{array}$} & \multirow{2}{*}{$\begin{array}{c}\text { SD } \\
1.15\end{array}$} \\
\hline & & & 27.94 & 35.19 & & & & \\
\hline EBT 5 min after a cigarette $\left({ }^{\circ} \mathrm{C}\right)$ & 33.86 & 1.23 & 28.39 & 35.47 & 33.81 & 1.37 & 33.97 & 1.11 \\
\hline EBT 15 min after a cigarette $\left({ }^{\circ} \mathrm{C}\right)$ & 33.84 & 1.43 & 28.90 & 35.16 & 33.95 & 1.37 & 33.50 & 1.71 \\
\hline EBT 30 min after a cigarette $\left({ }^{\circ} \mathrm{C}\right)$ & 33.84 & 1.44 & 28.76 & 35.43 & 33.89 & 1.49 & 33.67 & 1.58 \\
\hline EBT 45 min after a cigarette $\left({ }^{\circ} \mathrm{C}\right)$ & 33.79 & 1.42 & 28.76 & 35.40 & 33.81 & 1.58 & 33.67 & 1.33 \\
\hline EBT 60 min after a cigarette $\left({ }^{\circ} \mathrm{C}\right)$ & 33.51 & 1.53 & 28.14 & 35.33 & 33.58 & 1.61 & 33.26 & 1.61 \\
\hline $\mathrm{EBT}_{\mathrm{AUC}}\left({ }^{\circ} \mathrm{C}_{\text {min }}\right)$ & 18.83 & 44.15 & -101.73 & 179.23 & 37.36 & 41.94 & -17.59 & 23.64 \\
\hline
\end{tabular}

EBT - exhaled breath temperature; SD - standard deviation; AUC - area under the curve

and baseline and post-bronchodilator $\mathrm{FEF}_{75}$ (expressed as percentile) $(\mathrm{p}<0.05$ for all, Table 4$)$. In multivariate analysis, $\mathrm{EBT}_{\mathrm{AUC}}$ correlated independently with age, BMI, number of cigarettes smoked a day, baseline EBT, and baseline $\mathrm{FEF}_{75}$ $\left(\mathrm{R}^{2}=0.39, \mathrm{p}<0.001\right.$ for the model, Table 5).

\section{DISCUSSION}

The main result of our study in "healthy" smokers was the sensitivity and discriminative power of $\mathrm{EBT}_{\mathrm{AUC}}$ as a measure of airway reaction to acute cigarette smoke exposure, that is, of individual susceptibility of the airways to cigarette smoke toxicity.

The individual pattern of EBT change from baseline to one hour after a smoked cigarette $\left(\mathrm{EBT}_{\mathrm{AUC}}\right)$ independently correlated with age, and inversely with BMI, baseline EBT, number of cigarettes smoked per day, and lung function (index representing small airways). Although on average EBT reached maximum and plateaued between 5 and 30 min after smoking, this response was not uniform for all participants. In fact, there were two distinct responses,

Table 4 Significant univariate associations with $\mathrm{EBT}_{\mathrm{AUC}}(\mathrm{n}=55)$

\begin{tabular}{lcc} 
Variables & r & p-value \\
\hline Baseline EBT & -0.441 & 0.001 \\
\hline FEV $_{1} /$ FVC & -0.370 & 0.005 \\
\hline PB FEV $_{1} /$ FVC & -0.334 & 0.013 \\
\hline FEV $_{1}(\mathrm{z}$-score $)$ & -0.268 & 0.048 \\
\hline FEV $_{1}(\%$ predicted $)$ & -0.272 & 0.044 \\
\hline FEV $_{1} / \mathrm{FVC}$ (z-score) & -0.343 & 0.010 \\
\hline FEV $_{1} /$ FVC (percentile) & -0.339 & 0.011 \\
\hline FEF $_{75}($ percentile) & -0.275 & 0.042 \\
\hline PB FEV $_{1}(\%$ predicted) & -0.268 & 0.048 \\
\hline PB FEV $_{1} /$ FVC (z-score) & -0.296 & 0.028 \\
\hline PB FEV $_{1} /$ FVC (percentile) & -0.334 & 0.013 \\
\hline PB FEF $_{75}$ (percentile) & -0.269 & 0.047 \\
\hline
\end{tabular}

EBT - exhaled breath temperature; AUC - area under the curve; $\mathrm{SD}$ - standard deviation; FVC - forced vital capacity; $\mathrm{FEV}_{1}$ forced expiratory volume in 1 second; $\mathrm{PB}$ - post-bronchodilator; $\mathrm{FEF}_{75}$ - forced expiratory flow at $75 \% \mathrm{FVC}$ significantly associated with participants' demographics, acute (cigarettes per day) and chronic cigarette smoke exposure (age, pack-years), and lung function. This was, however, visible only from regression analysis because this kind of analysis exhibits greater statistical power. These findings suggest that a specific combination of genetic and epigenetic factors makes some individuals more prone to the adverse effects of cigarette smoke. The integrated expression of such a trait (cigarette smoke sensitivity phenotype) could be identified by assessing the change in EBT after smoking a cigarette (a cigarette challenge test).

These findings also support our earlier ones in smokers at risk of developing COPD (4), in whom the rise in EBT from baseline to minute 5 after smoking turned out to be a significant predictor of newly developed COPD over two years of follow-up (4).

Tobacco smoke is a complex mixture of more than 4000 compounds, most of which toxic, and is considered the major cause of COPD (11). According to Tuder et al. (12), cigarette smoke damages lung tissue in three stages: 1) initial tissue damage, 2) injury progression, and 3) propagation of cell damage (12). In the initial stage, tobacco smoke damages the cells of the alveolar septum through oxidative stress, apoptosis, and inflammation. In the second stage, continued exposure causes destruction of the alveolar walls and the development of emphysema. In the final stage, already damaged tissue causes its own destruction by activating signalling pathways which amplify the reuptake of pro-inflammatory cells and the expression of chemokines and cytokines (12).

Changes in EBT in this study seem to be associated with changes in vascularity (vasodilation or vasoconstriction). Numerous studies have tried to elucidate the development of COPD, but gaps remain in our understanding of the role of the airway vasculature, most likely because it is methodologically difficult to measure bronchial blood flow (13). Although earlier research suggests that pulmonary circulation is the one responsible for heat exchange in the airways between air and mucosa (14-16), McFadden et al. (17) believe that it is submucosal bronchial circulation that controls the temperature of exhaled air and causes the airways to narrow. Still, it is not clear if increased or 
Table 5 Multivariate regression analysis for $\operatorname{EBT}_{\mathrm{AUC}}(\mathrm{n}=55)$

\begin{tabular}{lcccccc} 
& B & SE (of B) & b & SE (of b) & t (49) & p-value \\
\hline Intercept & & & 448.426 & 119.586 & 3.750 & 0.000 \\
\hline Age $($ years) & 0.268 & 0.121 & 1.304 & 0.586 & 2.224 & 0.031 \\
\hline BMI $(\mathrm{kg} / \mathrm{m})$ & -0.291 & 0.120 & -3.187 & 1.313 & -2.427 & 0.019 \\
\hline Cigarettes per day & -0.202 & 0.114 & -1.173 & 0.658 & -1.782 & 0.081 \\
\hline Baseline EBT $\left({ }^{\circ} \mathrm{C}\right)$ & -0.364 & 0.113 & -10.846 & 3.374 & -3.215 & 0.002 \\
\hline $\mathrm{FEF}_{75}$ (percentile) & -0.246 & 0.114 & -0.411 & 0.190 & -2.165 & 0.035
\end{tabular}

Regression summary for the dependent variable $\mathrm{EBT}_{\mathrm{AUC}}, \mathrm{R}=0.625, \mathrm{R}^{2}=0.391, \mathrm{~F}(5,49)=6.291, \mathrm{p}<0.001$. AUC - area under the curve; $\mathrm{B}$ - standardised regression coefficients; $\mathrm{b}$ - raw regression coefficients; BMI - body mass index; EBT - exhaled breath temperature; $\mathrm{FEF}_{75}$ - forced expiratory flow at $75 \% \mathrm{FVC}$

decreased vascularity is associated with the development of COPD. Two histological studies showed diminished bronchial vasculature in a COPD population $(18,19)$, which was later confirmed by more recent studies $(20,21)$. On the other hand, based on the presence of chronic inflammation of the airways, a vascular proliferation could be expected, at least in some COPD phenotypes (22).

The inverse association with the number of cigarettes per day found in our study could point to two distinct mechanisms: 1) lower intrinsic reactivity, or 2) too short washout time from the last smoked cigarette in participants with higher cumulative daily exposure (23). The second mechanism is supported by the inverse association of baseline EBT with $\mathrm{EBT}_{\mathrm{AUC}}$. Higher baseline EBT is associated with lower reactivity to repeated acute exposure to cigarette smoke or an already present level of inflammation and higher vascularity like in other inflammatory disorders of the airways (23-25). Our participants, however, did not show any pathology suggesting COPD. Lower EBT and EBT dynamics in patients with COPD can suggest lower heat exchange between air and airway mucosa because it is obstructed by hypersecretion of mucus and/or reduced vascularity as a consequence of morphological changes of the blood vessels (26).

The finding of significant inverse association between EBT $_{A U C}$ and BMI in our participants may be owed to increased arterial stiffness found in obese population and therefore lower vascular reactivity (27).

Hogg et al. (28) reported contribution of the small airways to the total airway resistance in normal lungs, but also a four to forty-fold increase in small airway resistance in patients with emphysema. Several studies have confirmed that pathological changes in the small airways do not necessarily entail spirometric abnormalities consistent with COPD diagnosis, so these pathological changes are also known as the "silent zone" of the lungs $(29,30)$. Although mid-expiratory flow rates have been used to detect small airway dysfunction, they were not used for follow up because of a high degree of variability, which is why little has been known about the role of small airway dysfunction in the development of COPD until quite recently $(31,32)$. The ability to distinguish between the small airway damage and emphysema has been improved by the recent development of parametric response mapping, which allows information from all lung voxels in an inspiratory multiple detector CT scan to be assigned to voxels present on an expiratory scan, making it possible to identify parts of the lungs with functional small airway disease (33). Boes et al. (34) used parametric response mapping analysis to monitor the progression of functional small airway disease and emphysema over a year and concluded that it was a transitional stage between normal lung and emphysema. Our results show inverse association between $\mathrm{EBT}_{\mathrm{AUC}}$ and the lung function parameter representing small airway dysfunction $\left(\mathrm{FEF}_{75}\right)$, which suggests that $\mathrm{EBT}_{\mathrm{AUC}}$ could serve as a non-invasive marker of early pathological changes in smokers.

The limitations of our study lie in a relatively small sample, cross-sectional design of the study, and the use of spirometry to measure lung function parameters. However, the protocol using $\mathrm{EBT}_{\mathrm{AUC}}$ showed to be highly reproducible and in line with other research of early changes in COPD, including our own follow-up study (4).

Our current findings suggest that the dynamics of EBT after smoking a cigarette could be associated with bronchial vasculature and small airway dysfunction, which corroborates the results of our previous study from a different perspective and supports that EBT has a potential as a non-invasive early risk predictor of COPD in smokers.

\section{Conflict of interest}

None to declare.

\section{REFERENCES}

1. Mathers CD, Loncar D. Projections of global mortality and burden of disease from 2002 to 2030. PLoS Med 2006;3:e442. doi: 10.1371/journal.pmed.0030442

2. Singh D. Small airway disease in patients with chronic obstructive pulmonary disease. Tuberc Respir Dis (Seoul) 2017;80:317-24. doi: 10.4046/trd.2017.0080

3. Popov TA, Kralimarkova TZ, Labor M, Plavec D. The added value of exhaled breath temperature in respiratory medicine. J Breath Res 2017;11:034001. doi: 10.1088/1752-7163/ aa7801

4. Labor M, Vrbica Ž, Gudelj I, Labor S, Jurić I, Plavec D. Exhaled breath temperature as a novel marker of future development of COPD: results of a follow-up study in 
smokers. COPD $2016 ; 13: 741-9$. doi: $10.3109 / 15412555.2016 .1164129$

5. Vrbica Ž, Labor M, Gudelj I, Labor S, Jurić I, Plavec D; MARKO study group. Early detection of COPD patients in GOLD 0 population: an observational non-interventional cohort study - MARKO study. BMC Pulm Med 2017;17:36 doi: 10.1186/s12890-017-0378-6

6. Miller MR, Hankinson J, Brusasco V, Burgos F, Casaburi R, Coates A, Crapo R, Enright P, van der Grinten CP, Gustafsson P, Jensen R, Johnson DC, MacIntyre N, McKay R, Navajas D, Pedersen OF, Pellegrino R, Viegi G, Wanger J; ATS/ERS Task Force. Standardisation of spirometry. Eur Resp J 2005;26:319-38. doi: 10.1183/09031936.05.00034805

7. Quanjer PH, Tammeling GJ, Cotes JE, Pedersen OF, Peslin $\mathrm{R}$, Yernault JC. Lung volumes and forced ventilatory flows. Report Working Party Standardization of Lung Function Tests, European Community for Steel and Coal. Official Statement of the European Respiratory Society. Eur Respir J 1993;16(Suppl 6):5-40. doi: 10.1183/09041950.005s1693

8. Quanjer PH, Stanojevic S, Cole TJ, Baur X, Hall GL, Culver BH, Enright PL, Hankinson JL, Ip MS, Zheng J, Stocks J; ERS Global Lung Function Initiative. Multi-ethnic reference values for spirometry for the 3-95-yr age range: the global lung function 2012 equations. Eur Resp J 2012;40:1324-43. doi: 10.1183/09031936.00080312

9. Popov TA, Dunev S, Kralimarkova TZ, Kraeva S, DuBuske LM. Evaluation of a simple, potentially individual device for exhaled breath temperature measurement. Resp Med 2007;101:2044-50. doi: 10.1016/j.rmed.2007.06.005

10. Popov TA, Kralimarkova TZ, Dimitrov DV. Measurement of exhaled breath temperature in science and clinical practice. Breathe 2012;8:186-92. doi: 10.1183/20734735.021811

11. Rodgman A, Perfetti TA. The Chemical Components of Tobacco and Tobacco Smoke. Boca Raton (FL): CRC Press; 2009.

12. Tuder RM, Yoshida T, Fijalkowka I, Biswal S, Petrache I. Role of lung maintenance program in the heterogeneity of lung destruction in emphysema. Proc Am Thorac Soc 2006;3:673-9. doi: 10.1513/pats.200605-124SF

13. Tuder RM, Yoshida T. Stress responses affecting homeostasis of the alveolar capillary unit. Proc Am Thorac Soc 2011;8:485-91. doi: 10.1513/pats.201103-029MW

14. McCullagh A, Rosenthal M, Wanner A, Hurtado A, Padley S, Bush A. The bronchial circulation-worth a closer look: a review of the relationship between the bronchial vasculature and airway inflammation. Pediatr Pulmonol 2010;45:1-13. doi: 10.1002/ppul.21135

15. Baile EM, Dahlby RW, Wiggs BR, Paré PD. Role of tracheal and bronchial circulation in respiratory heat exchange. J Appl Physiol (1985) 1985;58:217-22. doi: 10.1152/ jappl.1985.58.1.217

16. Serikov VB, Fleming NW. Pulmonary and bronchial circulations: contributions to heat and water exchange in isolated lungs. J Appl Physiol (1985) 2001;91:1977-85. doi: 10.1152/jappl.2001.91.5.1977

17. McFadden ER Jr, Pichurko BM, Bowman KF, Ingenito E, Burns S, Dowling N, Solway J. Thermal mapping of the airways in humans. J Appl Physiol (1985) 1985;58:564-70. doi: 10.1152/jappl.1985.58.2.564

18. Reid A, Heard BE. Preliminary studies of human pulmonary capillaries by India ink injection. Med Thorac 1962;19:2159. doi: $10.1159 / 000192221$
19. Cudkowicz L, Armstrong JB. The bronchial arteries in pulmonary emphysema. Thorax 1953;8:46-58. doi: 10.1136/ thx.8.1.46

20. Hashimoto M, Tanaka H, Abe S. Quantitative analysis of bronchial wall vascularity in the medium and small airways of patients with asthma and COPD. Chest 2005;127:965-72. doi: 10.1378/chest.127.3.965

21. Paredi P, Ward S, Cramer D, Dip M, Barnes PJ, Kharitonov SA. Normal bronchial blood flow in COPD is unaffected by inhaled corticosteroids and correlates with exhaled nitric oxide. Chest 2007;131:1075-81. doi: 10.1378/chest.06-2154

22. Zanini A, Chetta A, Saetta M, Baraldo S, Castagnetti C, Nicolini G, Neri M, Oliveri D. Bronchial vascular remodelling in patients with COPD and its relationship with inhaled steroid treatment. Thorax 2009;64:1019-24. doi: 10.1136/thx.2009.114629

23. Carpagnano GE, Ruggieri C, Scioscia G, Storto MM, Zoppo L, Foschino-Barbaro MP. Is the exhaled breath temperature sensitive to cigarette smoking? COPD 2016;13:642-6. doi: 10.3109/15412555.2016.1143458

24. Paredi P, Kharitonov SA, Barnes PJ. Faster rise of EBT in asthma: a novel marker of airway inflammation? Am J Respir Crit Care Med 2002;165:181-4. doi: 10.1164/ ajrccm.165.2.2103053

25. Xepapadaki P, Xatziioannou A, Chatzicharalambous M, Makrinioti H, Papadopoulos NG. Exhaled breath temperature increases during mild exacerbations in children with virusinduced asthma. Int Arch Allergy Immunol 2010;153:70-4. doi: $10.1159 / 000301581$

26. Paredi P, Caramori G, Cramer D, Ward D, Ciaccia A, Papi A, Kharitonov SA, Barnes PJ. Slower rise of exhaled breath temperature in chronic obstructive pulmonary disease. Eur Respir J2003;21:439-43. doi: 10.1183/09031936.03.00061902

27. Zebekakis PE, Nawrot T, Thijs L, Balkestein EJ, van der Heijden-Spek J, Van Bortel LM, Struijker-Boudier HA, Safar $\mathrm{ME}$, Staessen JA. Obesity is associated with increased arterial stiffness from adolescence until old age. J Hypertens 2005;23:1839-46. doi: 10.1097/01.hjh.0000179511.93889. e9

28. Hogg JC, Paré PD, Hackett TL. The contribution of small airway obstruction to the pathogenesis of chronic obstructive pulmonary disease. Physiol Rev 2017;97:529-52. doi: 10.1152/physrev.00025.2015

29. Stockley JA, Cooper BG, Stockley RA, Sapey E. Small airways disease: time for a revisit? Int J Chron Obstruct Pulmon Dis 2017;12:2343-53. doi: 10.2147/COPD.S138540

30. Mead J. The lung's “quiet zone”. N Engl J Med 1970;282:13189. doi: 10.1056/NEJM197006042822311

31. Borrill ZL, Houghton CM, Woodcock AA, Vestbo J, Singh D. Measuring bronchodilation in COPD clinical trials. Br J Clin Pharmacol 2005;59:379-84. doi: 10.1111/j.1365-2125.2004.02261.x

32. Piorunek T, Kostrzewska M, Stelmach-Mardas M, Mardas M, Michalak S, Goździk-Spychalska J, Batura-Gabryel H. Small airway obstruction in chronic obstructive pulmonary disease: potential parameters for early detection. Adv Exp Med Biol 2017;980:75-82. doi: 10.1007/5584_2016_208

33. Galbán CJ, Han MK, Boes JL, Chughtai KA, Meyer CR, Johnson TD, Galban S, Rehemtulla A, Kazerooni EA, Martinez FJ, Ross BD. Computed tomography-based biomarker provides unique signature for diagnosis of COPD 
phenotypes and disease progression. Nature Med 2012;18:1711-5. doi: 10.1038/nm.2971

34. Boes JL, Hoff BA, Bule M, Johnson TD, Rehemtulla A, Chamberlain R, Hoffman EA, Kazerooni EA, Martinez FJ, Han MK, Ross BD, Galbán CJ. Parametric response mapping monitors temporal changes on lung CT scans in the subpopulations and intermediate outcome measures in COPD Study (SPIROMICS). Academic Radiol 2015;22:186-94. doi: 10.1016/j.acra.2014.08.015

Presječna studija dinamike temperature izdaha nakon popušene cigarete i njezina povezanost s promjenama plućne funkcije u pušača prediktivnima za rizik od KOPB-a

Temperatura izdaha (EBT) biomarker je upale i vaskularizacije dišnih putova za koji je utvrđeno da može predvidjeti nastanak KOPB-a. Cilj ove presječne studije bio je procijeniti potencijal EBT-a u identifikaciji “zdravih" pušača čiji su dišni putovi osjetljivi na toksični učinak duhanskoga dima uz rizik od nastanka KOPB-a. Taj se cilj planirao postići utvrđivanjem povezanosti dinamike EBT-a nakon popušene cigarete s demografskim karakteristikama (dob, spol, pušačka navika) i plućnom funkcijom ispitanika. U ispitivanje je bilo uključeno 55 aktivnih pušača obaju spolova u dobi od 29 do 62 godine, čiji je medijan izloženosti duhanskom dimu bio $15(10-71,8)$ pušačkih godina (pack-years). EBT je mjeren na početku te 5, 15, 30, 45 i 60 minuta nakon popušene cigarete. Plućnu funkciju mjerili smo spirometrijski, uz susljedni bronhodilatacijski test. Za analizu dinamike EBT-a koristili smo se analizom varijance te smo izračunali površinu ispod krivulje u odnosu na početno mjerenje $\left(\mathrm{EBT}_{\mathrm{AUC}}\right)$ te $\mathrm{EBT}_{\mathrm{AUC}}$ upotrijebili kao zavisnu varijablu. Multivarijatna regresijska analiza korištena je za utvrđivanje povezanosti $\mathrm{EBT}_{\mathrm{AC}} \mathrm{S}$ karakteristikama ispitanika, posebice s plućnom funkcijom. Prosječni $( \pm \mathrm{SD})$ izmjereni početni EBT bio je $33,42 \pm 1,50{ }^{\circ} \mathrm{C}$, a najveće značajno izmjereno povećanje zabilježeno je 5 minuta nakon popušene cigarete $\left(33,84(1,25)^{\circ} \mathrm{C}, \mathrm{p}=0,003\right)$. Bilo je potrebno 60 minuta kako bi se EBT vratio na početnu vrijednost. Utvrđena je značajna ponovljivost $\mathrm{EBT}_{\mathrm{AUC}}(\mathrm{ICC}=0,85, \mathrm{p}<0,001)$. Ispitivanjem je utvrđeno je da je $\mathrm{EBT}_{\mathrm{AUC}}$ značajno nezavisno povezan s dobi, indeksom tjelesne mase, brojem popušenih cigareta dnevno, početnim EBT-om te s početnim $\mathrm{FEF}_{75}\left(\mathrm{R}^{2}=0,39, \mathrm{p}<0,001\right.$ za model). Rezultati ove studije sugeriraju da EBT nakon popušene cigarete može biti koristan kao rani prediktor rizika od promjena koje su povezane s kroničnom izloženosti duhanskom dimu.

KJUČNE RIJEČI: temperatura izdaha; pušenje cigareta; rizik od KOPB-a; disfunkcija malih dišnih putova; toksičnost duhanskoga dima 